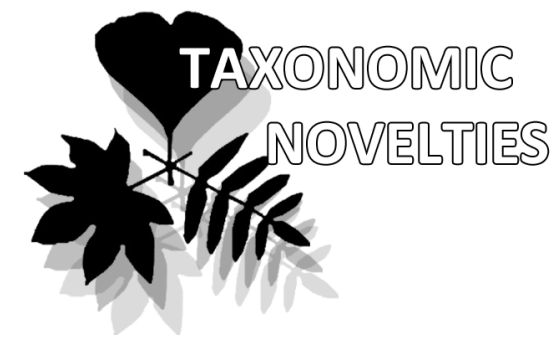

\title{
A New Species of Czekanowskia (Czekanowskiales) from the Middle Jurassic of Ordos Basin, China
}

\author{
Chunlin Sun ${ }^{1,2} *$, Hongshan Wang ${ }^{3}$, David L. Dilcher ${ }^{4}$, Tao Li ${ }^{2}$, \\ Yunfeng $\mathrm{Li}^{2}$, Yuling $\mathrm{Na}^{2}$
}

Chunlin Sun ${ }^{1,2 *}$

e-mail: clsun@jlu.edu.cn

Hongshan Wang ${ }^{3}$

e-mail: hwang@flmnh.ufl.edu

David L. Dilcher ${ }^{4}$

e-mail: dilcher@indiana.edu

$\mathrm{Tao} \mathrm{Li}^{2}$

e-mail: litao@jlu.edu.cn

Yunfeng $\mathrm{Li}^{2}$

e-mail: 499761747@qq.com

Yuling $\mathrm{Na}^{2}$

e-mail: 195912281@qq.com

${ }^{1}$ Key Laboratory for Evolution of Past Life and Environment in Northeast Asia, Ministry of Education, Changchun 130026, China

${ }^{2}$ Research Center of Palaeontology and Stratigraphy, Jilin University, Changchun 130026, China

${ }^{3}$ Florida Museum of Natural History, University of Florida, Gainesville, Florida 32611, USA

${ }^{4}$ Departments of Geology and Biology, Indiana University, Bloomington, Indiana 32611, USA

* corresponding author

Manuscript received: 28.07.2015

Review completed: 23.09.2015

Accepted for publication: 01.10.2015

Published online: 17.10.2015

\begin{abstract}
A B S T R A C T
The present paper focuses on the taxonomy of the genus Czekanowskia (Czekanowskiales). A new species, Czekanowskia (subg. Harrisella) ordosensis sp. nov., is described from the Middle Jurassic Yan'an Formation of Ordos Basin, China on the basis of epidermal structures for the first time. The discovery of the new species provides new information on the morphological and epidermal characters of Crekanowskia (subg. Harrisella) and increases our knowledge on its taxonomy. This discovery is significant for a better understanding of the diversity of the genus Crekanowskia during the middle Jurassic and the geological distribution of Crekanowskia (subg. Harrisella) in China. The analysis of the taphonomy suggests that Crekanowskia are seasonally deciduous trees or shrubs growing on the hillside and sloping fields along the meandering rivers, lakes and swamps in a vast sedimentary basin in warm temperate and temperate zones.
\end{abstract}

K e y w o r d s : Crekanowskia, Czekanowskiales, Middle Jurassic, Ordos Basin, China

\section{P E 3 Ю M E}

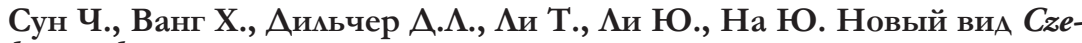
kanowskia (Czekanowskiales) из среднеюрских отможений бассейна Ордос, Китай. Основное внимание в статье уделяется таксономии рода Czekanowskia (Czekanowskiales). Crekanowskia (subg. Harrisella) ordosensis sp. nov. описывается из среднеюрских отложений формации Яньань бассейна Ордос, Китай, на основе эпидермальных структур миста. Открытие нового вила дает новую информацию о морфологических и эпидермальных признаках рода Czekanowskia (subg. Harrisella) и расширяет наши знания о его таксономии. Аанная находка имеет большое значение Аля понимания разнообразия рода Czekanowskia в средней юре и его распространении в геологическом времени в Китае. Анализ тафоценозов показывает, что Сұеkanowskia была представлена сезонно мистопадными Аеревьями или кустарниками, растущими на склонах гор и пологих участках вдоль речных АОАин, по берегам озер и болот в обширных осадочных бассейнах в теплоумеренной и умеренной зонах.

К м ю че в ы е с м о в а: Cqekanowskia, Czekanowskiales, среднеюрский период, бассейн Ордос, Китай

Переведено редколмегией

\section{INTRODUCTION}

Czekanowskiales (Pant 1957) is an enigmatic gymnospermous order flourished in the Mesozoic of the Northern Hemisphere. Krassilov $(1977,1997)$ suggested that it has remote affinities with the flowering plants and treated it in a group called Proangiosperms. It is now widely accepted that Czekanowskiales includes the genera Phoenicopsis Heer, Czelkanowskia Heer, Solenites Lindley et Hutton, Hartzia Harris, Sphenarion Harris, Arctobaiera Florin, ovulate cone Leptostrobus Heer and pollen cone Ixostrobus Raciborski (Krassilov 1968, 1972a, 1972b, Harris et al. 1974; Sun et al. 2009). Among these genera, Czekanowskia is one of the most common members. This genus was originally established by Heer (1876) based on the specimens from the Jurassic Irkutsk coal-bearing basin of eastern Siberia of Russia. Czekanowskia setacea Heer was designated as the type species.
Since then, many fossil leaves have been discovered from the Mesozoic floras throughout the Northern Hemisphere, especially in Eurasia, and they are generally described as $C_{z \ell-}$ kanowskia rigida Heer and C. setacea Heer based on the gross leaf morphology. Samylina \& Kiritchkova $(1991,1993)$ recognized three subgenera within the genus Czekanowskia based upon stomatal distribution and arrangements, i.e., subg. Crekanowskia (amphistomatic leaves with stomata arranged in files), subg. Harrisella (amphistomatic leaves with stomata arranged in bands, at least on the lower epidermis), and subg. Vachrameevia (hypostomatic leaves with stomata arranged in files or bands).

Although Crekanonskia leaves are quite common in the Mesozoic sediments of China, especially in northern China, its taxonomy was less well known based upon leaf cuticular structure (Li et al. 1988, Wu et al. 2002, Sun et al. 2009). In recent years, we have collected abundant Crekanowskia 
leaves from the Middle Jurassic Yan'an Formation of the Ordos Basin in northern China. Following Samylina and Kiritchkova's $(1991,1993)$ taxonomy, the genus Czekanowskia (subg. Harrisella) is recognized for the first time, and a new species Czekanowskia (subg. Harrisella) ordosensis sp. nov. is first described in this paper. The new species extends the geological and geographical distribution of this subgenus and its occurrence shows that this subgenus was an important member of Czekanowskia in the Middle Jurassic flora of northern China and Eurasia. Meanwhile, it also increases our knowledge in understanding the paleobiodiversity of Crekanowskia during the Middle Jurassic of northern China.

\section{GEOLOGICAL SETTING}

The specimens were collected from the Middle Jurassic coal-bearing Yan'an Formation of the northeastern area of the Ordos Basin, China (Fig. 1). The Ordos Basin is one of the large-scale Mesozoic sedimentary basins in China. The strata contain the Triassic-Cretaceous continental deposits. The oil, gas and coal resources were developed in the Triassic and Jurassic sediments. The Jurassic sediments were divided into four formations in the basin, in ascending order, the Lower Jurassic Fuxian Formation, the Middle Jurassic Yan'an and Zhiluo formations and the Middle or Upper Jurassic Anding Formation (Geological Institute of Chinese Academy of Geological Sciences 1980, Geological and Mineral Resources Bureau of Inner Mongolia Autonomous Region 1991, He et al. 2004).

The Yan'an Formation is well-developed and exposed in the northeastern area of the Ordos Basin. In this area, it can be subdivided into two members based on our field geological survey. The lower member is the main coal-bearing deposits, consisting of sandstones, siltstones, mudstones and coals, which were formed from sediments of alternate fluvial, lacustrine and swamp environments. The upper member is characterized by fine grained detrital rock which indicates lacustrine environments. We have collected abundant Crekanowskia leaves and fossils of various other plant groups, including bryophyte, ferns, cycads, ginkgos and co- nifers from the siltstone, mudstone and fine-grained sandstone beds of the lower part of the lower member (Fig. 2).

\section{MATERIAL AND METHODS}

Five specimens of Crekanowskia leaves preserved as compression are observed using an Olympus SZX10 microscope. Photographs were obtained under reflected light using a digital camera (Canon 5D Mark II). The cuticle of these specimens is suitable for maceration. The preparations were made following standard procedures (Dilcher 1974, Kerp 1990, Kerp \& Krings 1999). Prepared cuticle was observed under a scanning electron microscope (JSM-6700) and photographed at an acceleration voltage of $10 \mathrm{kV}$ at the Key Laboratory for Evolution of Past Life and Environment in Northeast Asia, Ministry of Education, Changchun, China.

All specimens and preparations are stored at the Research Center of Palaeontology and Stratigraphy of Jilin University, Changchun, China.

\section{SYSTEMATICS}

Order Czekanowskiales Pant 1957

Genus Czekanowskia (Heer) Harris and Miller 1974

Subgenus Czekanowskia (subg. Harrisella) Kiritchkova and Samylina 1991

Species Czekanowskia (subg. Harrisella) ordosensis sp. nov. (Figs. 3-5)

Diagnosis: Linear leaves in a bundle of six or seven attached on the short shoot; individual leaf more than $130 \mathrm{~mm}$ long, branching dichotomously once (occasionally twice) in the middle or upper portion, resulting ultimate leaf segments 1.4-1.6 mm wide. Leaf amphistomatic, sparse stomata longitudinally arranged in file on the upper epidermis; stomata longitudinally arranged in band on the lower epidermis with each band containing 2-3 files. Guard cells surrounded by four to six subsidiary cells. Anticlinal walls straight. Trichomes or papillae absent.

Description: The short shoot is $5 \mathrm{~mm}$ long and $2.5 \mathrm{~mm}$ wide without distinct scale leaves (Fig. 3A). There are five to seven linear leaves in each bundle. The individual leaf is more than $130 \mathrm{~mm}$ long and dichotomizes once, or occa-

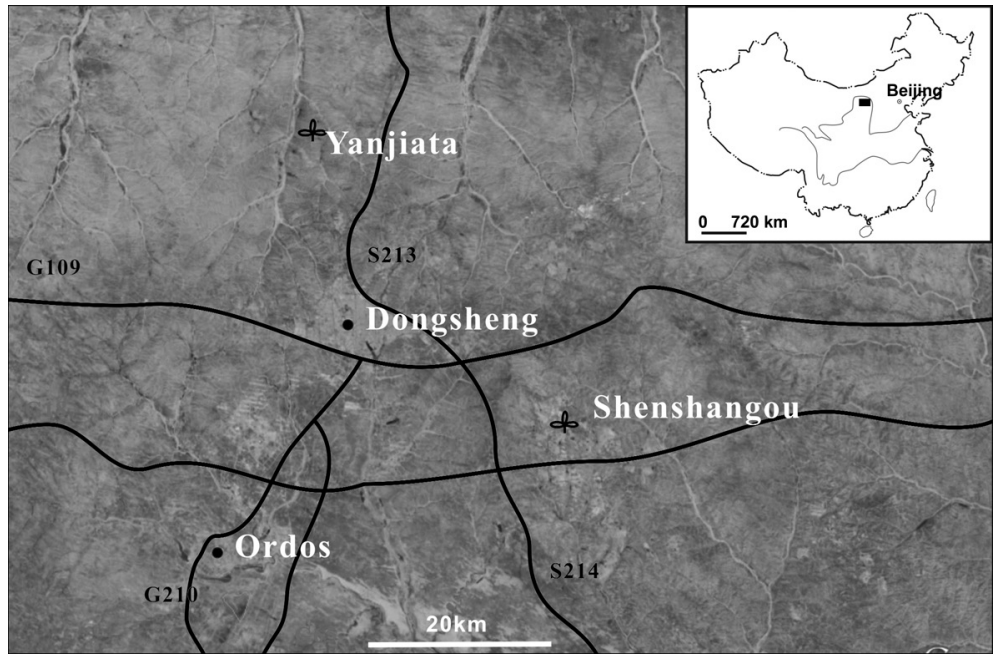

Figure 1 Map showing fossil plant localities from the Ordos Basin, China. Rectangle in the inset denotes the study area in the Ordos Basin in China

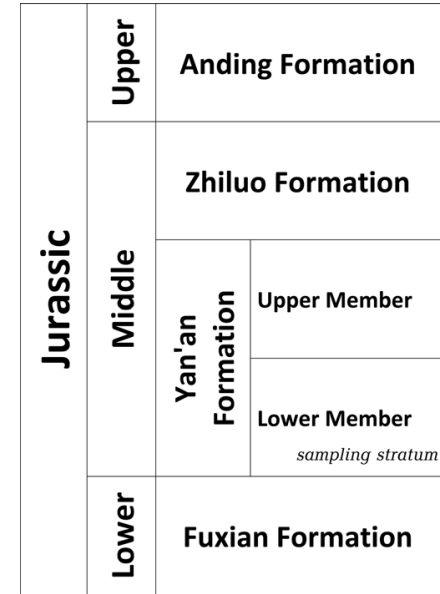

Figure 2 Generalized stratigraphic column of the Jurassic strata in the Ordos Basin, China. The plant fossils were collected from the lower member of the Yan'an Formation 


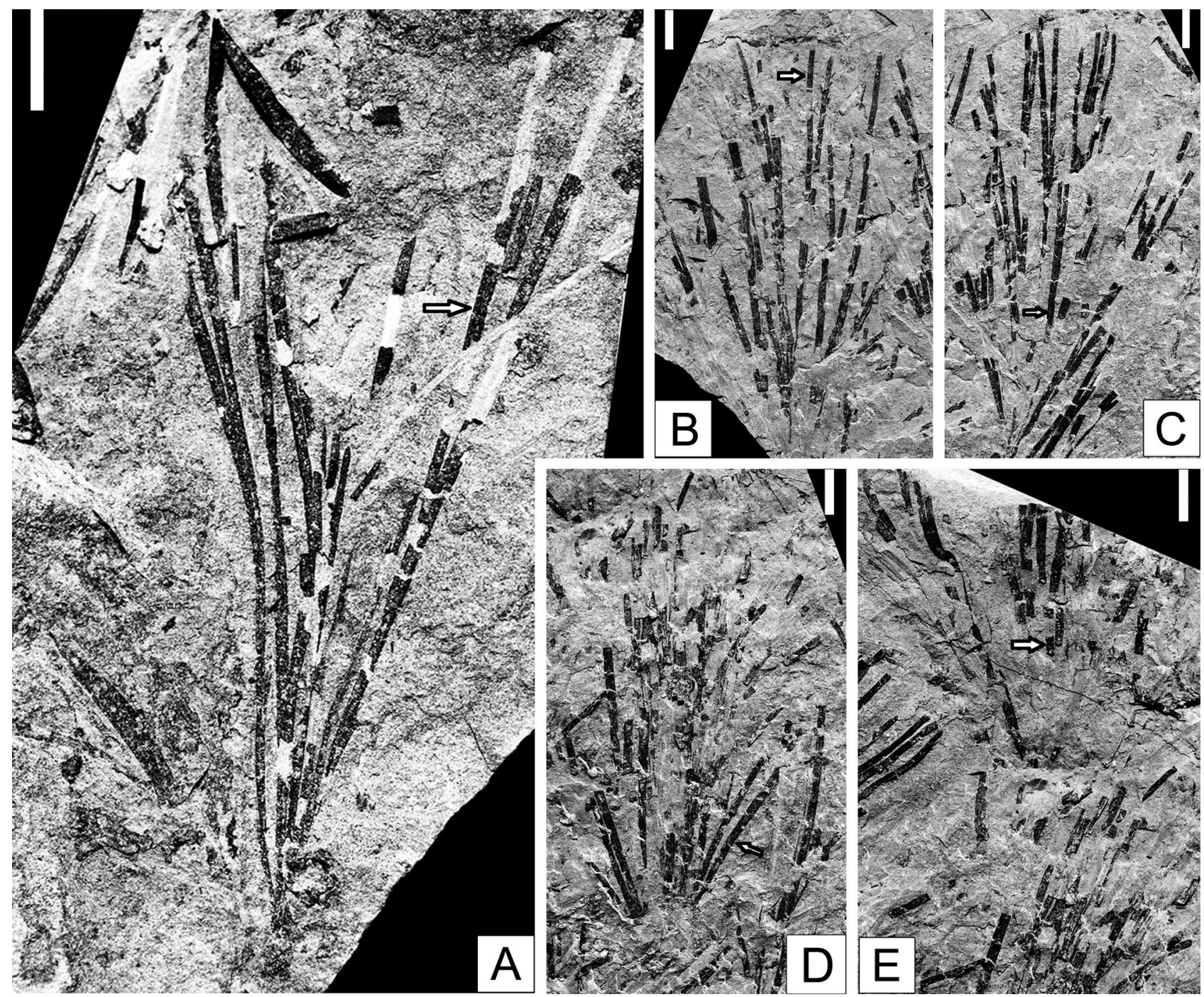

Figure 3 Leaves of Czekanowskia (subg. Harrisella) ordosensis sp. nov. from the Middle Jurassic Yan'an Formation, Ordos, Inner Mongolia, China. Arrows denote areas where cuticle was removed for preparation. All scale bars $=10 \mathrm{~mm}$.

A - Holotype, YJT062. Specimen collected from the Yanjiata locality. Note dichotomizing leaf segments on the left. B, C - Paratypes, SSG024, SS G025. Specimens collected from the Shenshangou locality. Note five leaves in B and at least 7 leaves in C. D, E- other specimens examined, SSG026, SSG027. Specimens collected from the Shenshangou locality

sionally twice, and is $1-1.5 \mathrm{~mm}$ wide at the lower portion and up to $1.8-2 \mathrm{~mm}$ wide before branching (Fig. 3A, B). The ultimate leaf segments are 1.4-1.6 $\mathrm{mm}$ wide. The veins are inconspicuous (Fig. 3A-E).

The cuticle was removed from the middle and distal portions of the leaf (Fig. 3). Leaf is amphistomatic. Both sparse stomata and ordinary cells are arranged in longitudinal files on the upper epidermis. The epidermal cells along the stomatal file are commonly rectangular, 30$50 \mu \mathrm{m}$ long and 15-20 $\mu \mathrm{m}$ wide, rarely isodiametric, 20$25 \mu \mathrm{m}$ long and 15-20 $\mu \mathrm{m}$ wide (Fig.3 A, B). The epidermal cells between the stomatal files are more elongated with pointed or truncate ends, $70-120 \mu \mathrm{m}$ long and 15-20 $\mu \mathrm{m}$ wide. The anticlinal cell walls of the ordinary epidermal cells are straight. Heavily cutinized structures are observed in the anticlinal walls of epidermal cells (Fig. 4C, D, Fig. 5C, G). Trichomes and papillae are absent (Fig. 4F; Fig. 5H).

There are 4-5 stomatal and non-stomatal bands on the lower epidermis (Fig. 5A). Non-stomatal bands are 150$180 \mu \mathrm{m}$ wide, composed of more elongated cells with trun- cated or pointed ends. The stomatal bands are 200-250 $\mu \mathrm{m}$ wide, and the ordinary epidermal cells are rectangular or irregularly square-shaped, 30-50 $\mu \mathrm{m}$ long and 15-20 $\mu \mathrm{m}$ wide. The anticlinal cell walls of the ordinary epidermal cells are straight. Longitudinally orientated stomata form two to three discontinuous rows in each stomatal band (Fig. 5B, G). The stomatal apparatuses are nearly rounded, 60-70 $\mu \mathrm{m}$ long and 50-60 $\mu \mathrm{m}$ wide. The guard cells are slightly sunken below the surface of subsidiary cells. They are commonly surrounded by five to six subsidiary cells, with one at each polar end and one or two on each lateral side (Fig. 5D, E, F). The subsidiary cells at the polar ends of the guard cells are short.

Comparison: Except for the new species, all nine other species of Crekanowskia (subg. Harrisella) have been reported from the Jurassic deposits. Among them, eight known species are from the former Soviet Union (Samylina \& Kiritchkova 1991), and one is from China (Sun et al. 2009). Morphologically, the new species is comparable with Crekanowskia (subg. Harrisella) mchatica Kiritchkova and 

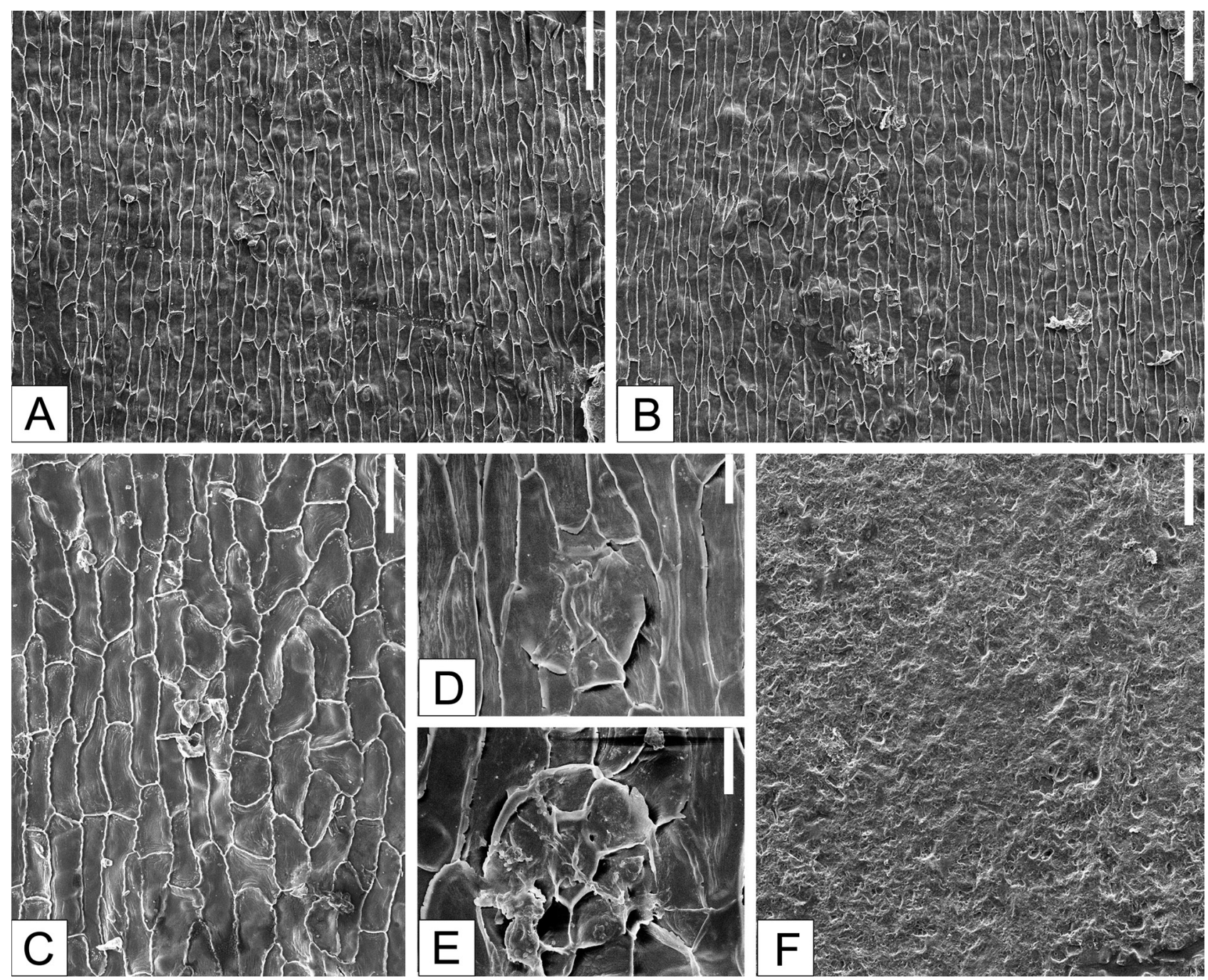

Figure 4 SEM images of the upper cuticle of Czekanowskia (subg. Harrisella) ordosensis sp. nov. Cuticle removed from Figure 3A, B. Scale bars $=100 \mu \mathrm{m}$ in A, B, F; $50 \mu \mathrm{m}$ in C; $20 \mu \mathrm{m}$ in D, E.

A, B - inner surface showing sparse stomata longitudinally arranged in file on the upper epidermis. C - inner surface showing epidermal cell shape. D, E - inner surface showing stomatal apparatuses. Note the guard cells and the subsidiary cells. F - outer surface showing smooth periclinal walls of the epidermal cells.

Samylina from the Middle Jurassic of northern Kazakhstan (Samylina \& Kiritchkova 1991, p. 84, pl. 57, text fig. 47), C\%. (subg. H.) robusta Kiritchkova and Samylina from the Early Jurassic of Central Asia (Samylina \& Kiritchkova 1991, p. 87, pl. 5, 59, text fig. 49), C\%. (subg. H.) vera Kiritchkova and Samylina from the Upper Jurassic of Siberia. However, these species are apparently different from the new species in the presence of papillae on the periclinal walls of both lower and upper epidermis. The other species from the former Soviet Union can be distinguished from the new species by their leaf size, the number of stomatal bands in each leaf segment and stomatal files in each band. The new species is very similar to $C_{\text {}}$. (subg. $H$.) chinensis Sun et al. from the Middle Jurassic of Inner Mongolia of China in gross leaf morphology (Sun et al. 2009, pp. 1185-1187, figs. 3-6). They significantly differ in that the leaf of $C_{\text {}}$ : (subg. H.) chinensis Sun et al. dichotomizes two or three times to give rise to narrower leaf segments (0.6-1 mm wide), and there are two files of stomata in each stomatal band on the upper epidermis.
Holotype: YJT062 (Fig. 3A).

Paratypes: SSG024, SSG025 (Fig. 3B, C).

Repository: The Research Center of Palaeontology and Stratigraphy of Jilin University, China.

Type locality: Yanjiata coal mine, Dongsheng, Inner Mongolia, China.

Stratum typicum: Gray siltstone of the lower member of Yan'an Formation.

Etymology: The specific epithet ordosensis refers to the Ordos Basin where the specimens were collected.

\section{DISCUSSION}

The genus Crekanowskia is quite common in the Mesozoic terrestrial deposits of Eurasia. About 90 known species have been described based upon the differences of cuticular features and gross leaf morphology. Among these species, ca. 70 species were assigned to the subgenus Czekanowskia (subg. Czekanowskia) (Johansson 1922, Harris 1926, 1935, Harris \& Miller 1974, Kimura \& Ohana 1979, Li et. al. 1988, Doludenko \& Rasskazova 1972; Doludenko \& 

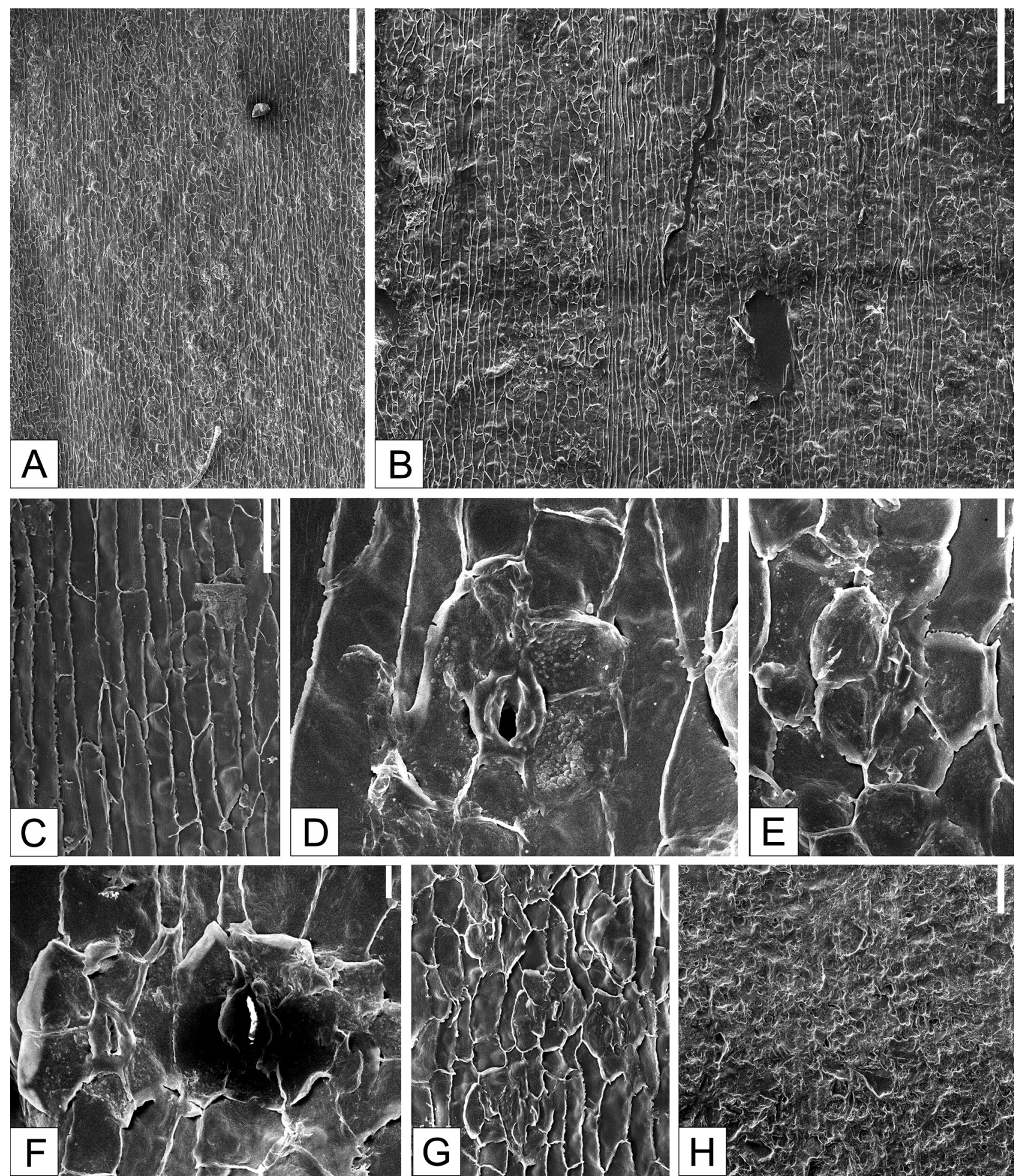

Figure 5 SEM images of the lower cuticle of Crekanowskia (subg. Harrisella) ordosensis sp. nov. Cuticle removed from Figure 3A, B, C, D. Scale bars $=200 \mu \mathrm{m}$ in A, B; $50 \mu \mathrm{m}$ in C, G; $10 \mu \mathrm{m}$ in D, E, F; $100 \mu \mathrm{m}$ in $\mathrm{H}$.

A, B - inner surface showing stomata longitudinally arranged in band. C - inner surface showing epidermal cells in the non-stomatal band. D-F - inner surface showing stomatal apparatuses. G - inner surface showing dense stomatal apparatuses in the stomatal band. H - outer surface showing smooth periclinal walls of epidermal cells.

Orlovskava 1976, Samylina \& Kiritchkova 1991, 1993, Ash 1994, Kostina 1999, 2004). Most of them were collected from the former Soviet Union. Two other subgenera have a relatively small number of species. Nine known species were assigned to the subgenus Czekanowskia (subg. Harrisella), with eight from the former Soviet Union and one from China (Samylina \& Kiritchkova 1991, Sun et al. 2009). Nine species were assigned to the subgenus Czekanowskia (subg. Vachrameevia), with seven known species from the former Soviet Union (Samylina \& Kiritchkova 1991) and one known species (Sun et al. 2009) and one undefined species (Wu et al. 2002) from China. The discovery of the 
new species further provides new morphological and epidermal data and increases our taxonomic knowledge of Czekanowskia (subg. Harrisella).

Our literature survey indicates that two species of Cqekanowskia (subg. Harrisella) were reported from the middle Early Jurassic of Kazakhstan and Central Asia, one from the Early to Middle Jurassic of Kazakhstan, five from the Middle Jurassic of Kazakhstan and north China, and one from the Late Jurassic of western Siberia. Their geological distribution implies that this subgenus was less diverse during the Early Jurassic. During the Middle Jurassic its diversity reached the maximum, and in the Late Jurassic the number was remarkably reduced, possibly as a result of the arid climatic condition (Samylina \& Kiritchkova, 1991, Sun et al. 2009). Crekanowskia leaves are quite rich in the Middle Jurassic Yan'an Formation of the Ordos Basin. The new species represents the first fossil record of Crekanowskia (subg. Harrisella) from the Ordos Basin based upon the epidermal structures. Its discovery is significant for a better understanding of the biodiversity of the genus $C_{z e-}$ kanowskia during the Middle Jurassic and the spatial and temporal distribution of Czekanowskia (subg. Harrisella) in China and other parts of Eurasia.

In several open coal mine pits of the Yan'an Formation, abundant Czekanowskia leaves with short shoot are densely and imbricately compressed on the bedding planes of the grey shale and siltstone, which is interpreted as deposited in a shallow water lake on a flood plain. Their mode of preservation indicates that these leaves had undergone no or minimal transportation within the vicinity of their living area before they were buried in the sediments. The large amount of the leaves with short shoots preserved together may also indicate that the genus Crekanowskia may be seasonally deciduous trees or shrubs growing on the hillside and sloping fields along the meandering streams, lakes and swamps in a vast sedimentary basin.

The new Crekanowskia also is significant because of its paleoclimatic role (Sun et al. 1992, 2000). Previous paleoclimatic interpretations of the Yan'an Formation were seasonally warm and humid climatic environments (Ge et al. 2006, Tanner et al. 2012). According to Ge et al. (2004, 2005,2006 ) and our preliminary study, the plant fossils that are present in the Yan'an Formation from the northeastern area of the Ordos Basin contain diverse plant groups. Among them, Ginkgoales, Czekanowsliales and Coniferales are the dominant groups, with frequently seen taxa such as Ginkgo or Ginkgoites, Baiera, Sphenobaiera, Eretmophyllum, Phoenicopsis, Crekanowskia, Solenites, Podozamites, Pityophyllum, and Elatides. They are followed by Hepaticopsida, Equisetales and Filicales, such as Hepaticites, Equisetites, Neocalamites, Cladophlebis, Coniopteris and Eboracia, and Bennettitales, mostly Perophyllum and Anomozamites. In general, the composition of the Yan'an flora indicates that the flora grew under a humid condition in warm-temperate climate zone with seasonal fluctuation.

The members of the order Czekanowskiales have been found in the Mesozoic of the Northern Hemisphere previously and ranged from the humid temperate regions of Siberia, Inner Mongolia and northern China to the humid tropical or subtropical regions near the Tethys and southern China (Vakharameev 1964, 1991, Sun 1992, Ash 1994; Sun et al. 2009, Kostina \& Herman 2013, Kostina et al. 2015). Especially in the Ordos Basin, the Middle Jurassic Crekanowskia-bearing strata contain coals and diverse floras which include water-loving taxa such as liverworts, horsetails and ferns. In contrast, the Upper Jurassic red beds in southern Eurasia and northeastern China do not yield Carekanowskia. Therefore, Czekanowskia can be considered as an indicator of humid climatic condition. Several characters of the new species are consistent with growth in a humid, rather than an arid climate. These characters include thin amphistomatic leaves, delicate cuticles and shallow stomatal pits that are always kept open and surrounded by undeveloped bulges. In conclusion, the presence of the new species of Crekanowskia and other taxa of Czekanowskiales in the Middle Jurassic coal-bearing Yan'an Formation supports the interpretation that the Ordos Basin was located in the warm-temperate zone with seasonal change and the climate was humid at least in the rainy season during the Middle Jurassic.

\section{ACKNOWLEDGEMENTS}

The authors sincerely thank Dr. Sofia S. Barinova, Head of Laboratory of Biodiversity and Ecology, Institute of Evolution, University of Haifa, who invited us to write this paper in honor of Dr. and Professor Valentin A. Krassilov, our dear friend and colleague. This study was supported by the National Natural Science Foundation of China (41172009), Specialized Research Fund for the Doctoral Program of Higher Education grant (2010061110034), China Geological Survey Grant (1212011120149) and Project «111», China.

\section{LITERATURE CITED}

Ash, S.R. 1994. First occurrence of Czekanowskia (Gymnospermae, Czekanowskiales) in the United States. Review of Palaeobotany and Palynology 81:129-140.

Dilcher, D.L. 1974. Approaches to the identification of angiosperm leaf remains. Botanical Review 40:1-157.

Doludenko, M.P. \& E.R. Orlovskaya 1976. Jurassic flora of the Karatau. Nauka, Moskva, 262 pp. (in Russian). [Аолуденко М.П., Орловская Э.Р. 1976. Юрская флора Каратау. Москва: Наука. 262 с.].

Doludenko, M.P. \& E.S. Rasskazova 1972. Ginkgoales and Czekanowskiales of the Irkutsk Basin. Trudy Geologicheskogo Instituta AN SSSP 230:7-43 (in Russian). [Аолуденко М.П., Рассказова Е.С. 1972. Гинкговые и чекановскиевые Иркутского бассейна / / Труды Геологического института АН СССР. Вып. 230. С. 7-43].

Florin, R. 1936. Die fossilen Ginkgophyten von Franz-Joseph-Land nebst Erörterungen über vermeintliche Cordaitales Mesozoischen Alters, I. Spezieller Teil. Palaeontographica B81(3-6): 71-173.

Ge, Y.H., C.L. Sun \& M.X. Liu 2004. Discovery of Middle Jurassic flora from Gaotouyao area in northeastern margin of Ordos Basin. Global Geology 23(2):107-111 (in Chinese with English abstract).

Ge, Y.H., C.L. Sun \& M.X. Liu 2005. Stratigraphic division and correlation of the Yan'an Formation in the northeastern margin of the Ordos Basin, China. Journal of Stratigraphy 31(2):151-156 (in Chinese with English abstract).

Ge, Y.H., C.L. Sun \& M.X. Liu 2006. The flora from the Middle Jurassic Yan'an Formation in the northeastern 
margin of Ordos Basin and discussion on the palaeoclamate. Journal of Jilin University (Earth Science Edition) 36(2): 164-168 (in Chinese with English abstract).

Geological Institute of Chinese Academy of Geological Sciences (eds.) 1980. Mesozoic stratigraphy and paleontology from Shanganning Basin. Vol.1. Geological Publishing House, Beijing, 212 pp. (in Chinese).

Geological and Mineral Resources Bureau of Inner Mongolia Autonomous Region (eds.) 1991. Regional geology of Inner Mongolia autonomous region. Geological Publishing House, Beijing (in Chinese with English abstract).

Harris, T.M. 1926. The Rhaetic flora of Scoresby Sound, East Greenland. Meddelelser om Gronland 68:45-148.

Harris, T.M. 1935. The fossil flora of Scoresby Sound, East Greenland. 4. Ginkgoales, Coniferales, Lycopotales, and isolated fructification. Meddelelser om Gronland 112:1-176.

Harris, T.M. 1951. The fructification of Crekanowskia and its allies. Philosophical Transactions of the Royal Society B: Biological Sciences 235:483-508.

Harris, T.M., J. Miller 1974. Czekanowskiales. In: The Yorkshire Jurassic flora. Vol IV (T.M. Harris, W. Millington \& J. Miller, eds.), pp. 79-146. British Museum (Natural History), London.

He, Z.X., H. Yang \& X.Q. Yuan 2004. Atlas of geology profile in Ordos Basin. Petroleum Industry Press, Beijing (in Chinese).

Heer, O. 1876. Beiträge zur Jura-Flora Ostsibiriens und des Amurlandes. Mémoires de l'Academie Imperiale des Sciences de Saint-Petersbourg 22:1-222

Johansson, N. 1922. Die rätische Flora der Kohlengruben bei Stabbarp und Skromberga in Schonen. Kungliga Svenska Vetanskapsakademiens Handlingar 63:1-78.

Kerp, H., 1990. The study of fossil gymnosperms by means of cuticular analysis. Palaios 5:548-569.

Kerp, H. \& M. Krings 1999. Light microscopy of cuticles. In: Fossil plants and spores: modern techniques (T.P. Jones \& N.P. Rowe, eds.), pp. 52-56. Geological Society, London.

Kimura, T., T. Ohana 1979. Crekanowskia nipponica sp nov. from the Upper Cretaceous Omichidani Formation, Ishikawa prefecture in the inner zone of Central Japan. Proceedings of the Japan Academy 54:595-600.

Kostina, E.I. 1999. Czekanowskiales from the Jurassic deposits of the Kansk Coal Basin (Siberia). Paleontological Journal 33:577-584.

Kostina, E.I. 2004 Jurassic flora of the Kansk coal-beering basin. In: Trudy Geologicheskogo Instituta (M.A. Akhmet'ev, ed.), pp. 1-200, Geos, Moskva (in Russian). [Костина Е.И. 2004. Юрская флора Канского угленосного бассейна / / Труды Геологического института / отв. реА. М.А. Ахметьев. Москва: ГЕОС. 200 с.]

Krassilov, V.A. 1968. A new group of Mesozoic gymnosperms: Czekanowskiales. Doklady Akademii Nauk SSSR
178:942-945 (in Russian). [Красилов В.А. 1968. Новая группа мезозойских голосеменных - Czekanovskiales // Аоклады АН СССР. Т. 178. С. 942-945].

Krassilov, V.A. 1972 b. Mesozoic flora of Bureya River. Ginkgoales and Crekanowskiales. Nauka, Moscow, 150 pp. (in Russian). [Красилов В.А. Мезозойская флора реки Буреи (Ginkgoales и Czekanowskiales). М.: Наука, 1972 б. 150 с.].

Krassilov, V.A. 1972b. On morphology and systematics of ginkgos and czekanowskias. Paleontologicheskii Zhurnal 1: 113-118 (in Russian). [Красилов В.А. 1972. О морфомогии и систематике гинкговых и чекановскиевых // Пацеонтологический журнац. № 1. С. 113-118].

Krassilov, V.A. 1977. The origin of angiosperms. Botanical review 43(1):143-176.

Krassilov, V.A. 1997. Angiosperm Origins: Morphological and Ecological Aspects. Pensoft, Sofia, 270 pp.

Li, P.J., Y.L. He, X.W. Wu, S.W. Mei \& B.Y. Li 1988. Early and Middle Jurassic strata and their floras from northeastern border of Qaidam Basin, Qinghai. Nanjing University Press, Nanjing 231 pp. (in Chinese with English summary).

Pant, D.D. 1957. The classification of gymnospermous plants. Palaeobotanist 6:65-70.

Samylina, V.A. \& A.I. Kiritchkova 1991. The genus Crekanowskia (systematics, history, distribution and stratigraphic significance). Nauka, Leningrad, 144 pp. (in Russian). [Самылина В.А., Киричкова А.И. 1991. Род Сzekanowskia: систематика, история, распространение, значение Аля стратиграфии. Аенинград: Наука. 144 с.].

Samylina, V.A. \& A.I. Kiritchkova 1993. The genus Crekanowskia Heer: principles of systematics, range in space and time. Review of Palaeobotany and Palynology 79:271-284.

Sun, C.L. 1992. The division of the Early Jurassic floristic province of the Eurasia continent. Journal of Changchun University of Earth Science (Collection of Doctoral dissertations): 178-187 (in Chinese with English abstract).

Sun, C.L., D.L. Dilcher, H.S. Wang, G. Sun \& Y. Ge 2009. Crekanowskia from the Jurassic of Inner Mongolia, China. International Journal of Plant Sciences 170(9):1183-1194.

Sun, C.L., T. Li, Y.W. Sun et al. 2000. Early Jurassic fossil cycads from the Yihe Basin in southern Jilin Province: paleoclimatic significance. Geology and Resources 19(1):1-8 (in Chinese with English abstract).

Tanner, L.H., X. Wang, A.C. Morabito 2012. Fossil charcoal from the Middle Jurassic of the Ordos Basin, China and its paleoatmospheric implications. Geoscience Frontiers 3(4):493-502.

Wu, X.W., S.H. Deng, Y.L. Zhang 2002. Fossil plants from the Jurassic of Chaoshui Basin, Northwest China. Palaeoworld 14:136-201 (in Chinese with English abstract). 